\title{
Deep brain stimulation (DBS) in resistant mental disorders
}

\author{
Głęboka stymulacja mózgu (DBS) w lekoopornych zaburzeniach psychicznych
}

\section{Małgorzata Romaniuk ${ }^{1}$ ABCDEF, https://orcid.org/0000-0001-8838-6291, Konrad Suswał ${ }^{1}$ ABCDE, Aleksandra Skałecka ${ }^{1}$ ABCE, Maria Gromek ${ }^{1}$ BCDE, Martyna Kozłowska ${ }^{1}$ CEF, Paweł Krukow ${ }^{2}$ DEF, https://orcid.org/0000-0001-9497-2713}
${ }^{1}$ Psychiatry Student Research Group I Department of Psychiatry, Psychotherapy and Early Intervention, Medical University of Lublin
${ }^{2}$ Department of Clinical Neuropsychiatry, Medical University of Lublin

\begin{abstract}
Introduction: Deep Brain Stimulation can directly alter brain activity in a controlled manner and the effect is reversible. The mechanism is that the electrode acts locally on neural activity, which is transferred to monosynchronous and multisynaptic network connections.

Methods: We present studies conducted on a group of patients that show an improvement in mental state after Deep Brain Stimulation.

Material: The diseases we included in our work are: Obsessive-Compulsive Disorder, Eating Disorder, Depression and Bipolar Affective Disorder.

Discussion: The use of deep brain stimulation can inhibit development of acute state of patients and improve both psychiatric features and the time of remission. The results indicate the greatest effectiveness of Deep Brain Stimulation in ObsessiveCompulsive Disorders.

Conclusions: Brain stimulation may be a promising therapeutic target in mental illness. In a properly selected location, it can contribute to a significant clinical improvement however further research in this direction is necessary.
\end{abstract}

Keywords: deep brain stimulation, drug-resistant, neuromodulation

\section{Streszczenie}

Wstęp: Głęboka stymulacja mózgu może bezpośrednio zmieniać aktywność mózgu w sposób kontrolowany, a efekt jest odwracalny. Mechanizm polega na miejscowym działaniu elektrody na aktywność neuronalną, która jest przekazywana do monosynchronicznych i wielosynaptycznych połączeń sieciowych.

Metoda: Przedstawiamy badania przeprowadzone na grupie pacjentów, które wskazują na poprawę stanu psychicznego po zastosowaniu głębokiej stymulacji mózgu.

Materiał: Jednostki chorobowe, które wzięliśmy pod uwagę w naszej pracy to: zaburzenia obsesyjno-kompulsyjne, zaburzenia odżywiania, depresja i Choroba Afektywna Dwubiegunowa.

Dyskusja: Zastosowanie głębokiej stymulacji mózgu może hamować rozwinięcie się ostrego stanu pacjentów i poprawiać zarówno cechy psychiatryczne, jak i wpływać na czas remisji. Wyniki wskazują na największą skuteczność głębokiej stymulacji mózgu w Zaburzeniach Obsesyjno-Kompulsyjnych.

Wnioski: Stymulacja mózgu może być obiecującym celem terapeutycznym w chorobach psychicznych. We właściwie dobranej lokalizacji może przyczynić się do znacznej poprawy klinicznej, jednak niezbędne są dalsze badania w tym kierunku.

Słowa kluczowe: głęboka stymulacja mózgu, lekooporność, neuromodulacja

\section{Introduction}

The modern understanding of the mechanisms of mental diseases and disorders emphasizes that the observable behavioral symptoms have a neurobiological basis, e.g. consisting in hypofunction and hyperfunction of certain parts of the brain, both cortical and subcortical. Therefore, it can be assumed that modulating the level of excitation of these structures should have a therapeutic 
effect. This assumption is based on deep brain stimulation (DBS), a method of treating neurological and psychiatric disorders in which electrical impulses are delivered to specific areas of the brain via implanted electrodes and a pulse generator [1].

DBS can directly alter brain activity in a controlled manner and the effect is reversible. The mechanism is that the electrode acts locally on neural activity, which is transferred to mono synchronous and multisynaptic network connections. DBS stimulation requires a surgical procedure in the selected area of the brain. The circuit that is used in DBS consists of a generator of rhythmic electrical activity, leading the signal to the corresponding nucleus of the brain, which is connected to the brain electrode with a special wire (connector). Potential risks connected with DBS include those associated with surgery, including a low $(<1 \%)$ risk of intracranial haemorrhage or infection, and associated neurological consequences. In addition, some patients may show transient neurological symptoms (e.g. eye movement disorder) that usually resolve spontaneously or with some pacemaker tuning [2].

Deep brain stimulation was first used in psychiatry in 1948 by Poola. He used this method in a patient with Parkinson's disease who also had symptoms of severe depression. At the time, it was believed that such stimulation could be helpful in controlling the side effects of medications, but the method was not fully understood [3].

In 2002, the FDA approved the use of stimulation of the subthalamic nucleus (STN) and the inner pale globule (Latin globus pallidus internus - GPi) in the treatment of Parkinson's disease, and since 2003 in personality disorders [4].

Currently, DBS is used, albeit off-label, in the treatment of major depression. However, the neuropathophysiology of mental illness remains poorly defined and the mechanism of DBS appears to be sitedependent [5].

\section{Methods}

We present studies conducted on a group of patients that show an improvement in mental state after using DBS. The entities we considered in our work are: Obsessive Compulsive Disorder, Eating Disorder, Depression and Bipolar Disorder.

The criteria we used to select publications:

- drug-resistant patients

- assessment of patients improvement according to Scale; Y-BOCS, HAMD, HDRS

- stimulating specific parts of the brain; nucleus accumbens, subcapsular gyrus of the rim, leg of the inner capsule

- duration of deep brain stimulation over 9 months

\section{Material}

\section{Obsessive Compulsive Disorder}

Obsessive-compulsive disorder (OCD) is a disorder in which two specific constituent parts are intrusive thoughts, defined as sudden thoughts intruding into the patient's opinion and intrusive activities, defined as behaviors, the basic of which is the reduction of tension caused by intrusiveness. The etiology of OCD is multifactorial - genetic, biological and environmental and DBS therapy is targeted at the biological basis of the disease. Deep brain stimulation in OCD aims to modificate abnormalities in neurological connections involving the orbitofrontal cortex, cingulate gyrus, and caudate nucleus [6].

Vicheva et al. assessed the affective state, global functioning, cognition and tolerability of DBS in 80 patients with drug-resistant OCD. The therapy was considered effective as it reduced the Yale-Brown Obsessive-Compulsive Scale (Y-BOCS) by an average of $38.68 \%$. Most adverse events were mild and transient. There were five serious complications due to surgery: intracerebral haemorrhage in three patients and perioperative infection related to implanted components in other two. Threatening effects related to mood were one completed suicide, three suicide attempts and four patients experienced suicidal thoughts and depression. Patients' affective status improved after stimulation [7].

Goodman et al. described the response of 70 patients treated with deep brain stimulation bilaterally in the area of the ventral anterior limb of the internal capsule (vALIC). The purposefulness of this electrode placement is based on the assumption that ablation of the fibers running through the anterior limb of the inner capsule will normalize the activity of over-synchronised network in OCD in the entire cortico-striatal-thalamocortical circumference. Moreover, there is an alternative, but complementary, hypothesis that DBS in the ventral striatum in OCD affects the balance between positive and negative valence systems in the brain in such a way that the direction of reward approach over harm avoidance changes towards the reward system rather than avoiding harm, which is reversal of the disorder present in OCD. Compulsions are designed to prevent negative effects and are not inherently satisfying, which distinguishes them from behavioral addictions. Unfortunately, insufficient monitoring of therapy can lead to an excessive search for reward, which manifests itself as transient states of hypomania. In the above study, after 12 months of follow-up, the Yale-Brown ObsessiveCompulsive Scale (Y-BOCS) decreased by $\geq 35 \%$ in $52 \%$ of cases and by $25-34 \%$ in $17 \%$ of cases. However, despite the growing body of evidence supporting the effectiveness of DBS in the treatment of OCD, the questionable safety 
profile of this method cannot be ignored. The authors noted 11 serious adverse events, including 2 in the form of postoperative infections. No intracerebral haemorrhage or seizures were reported. There were three suicide attempts without sequelae, one of which was classified as related to changes in stimulation. Transient hypomania occurred in $39 \%$ of patients [8].

Beszłej et al. present two cases in which DBS was used in obsessive-compulsive disorders. The described patients underwent electrode implantation in order to reduce pathologically overactive neural loops. Patients were monitored every two weeks for a period of 6 months, after which an attempt was made to turn off the pacemaker. The patients' condition worsened, and after re-switching on, a significant improvement in her mental state was achieved. Obsessions and compulsions decreased by 35\% points on the Y-BOCS scale from the initial score. The second patient, initially after the pacemaker implantation by neurosurgeons, obtained the same result as before the surgery. It was only during the second study that a decrease of $36 \%$ on the Y-BOCS scale was reported. Within three days of turning off the pacemaker, the patient's mood deteriorated significantly. After turning it on again, their well-being improved [9].

On the basis of numerous reports, it can be concluded that DBS is an effective method in the treatment of drug-resistant cases of obsessive-compulsive disorder. Unfortunately, there are still no established clinical predictors of which patients will respond to DBS. Moreover, the invasiveness of the method forces you to weigh the risk against the potential benefits [8].

\section{Anorexia nervosa}

Since evidence-based treatments of AN are scarce, it is crucial to investigate new treatment options. One of them is deep brain stimulation targeting the neurobiological mechanisms of the disease, associated with the variety of serotonin and dopamine receptors activity, indicating dysregulation of these systems involved in mood, anxiety, appetite and impulse control [10]. The etiopathogenesis of AN may be connected with such brain areas as the anterior insula, the striatum area, the anterior cingulate cortices responsible for the sensation of taste [11], the prefrontal cortex responsible for the ability to properly or inadequately control food intake [12] and brain structures related to the reward system such as the nucleus accumbens or the already mentioned anterior cingulate cortices.

The first studies (case series) on the use of DBS in the treatment of AN were carried out by researchers Sun et al. [13]. Preliminary results reported an average of $65 \%$ increase in body weight over a 38-month followup in four adolescent patients with AN treated with
DBS of the NAc. All four patients were suspended from school because of their severe physical and mental state of health before the implantation, and at last follow-up, three of them were able to continue school education. Lipsman et al. [14] found an improvement in BMI in 3 out of 6 adult patients with refractory AN during a 9-month follow-up period. However, there were reported several adverse events in their pilot study on subcallosal cingulate (ACC) DBS in AN, with one serious DBS-related adverse event in one patient - seizure during programming and hypophospataemia and a refeeding delirium in another patient. There is a risk of development of a refeeding syndrome in case of rapid weight gain following successful treatment with DBS, therefore such patients should be advised to increase their food intake gradually and under supervision of a dietary consultant. The somatic condition and the potential development of a refeeding syndrome should be closely monitored by a physician. Wei Liu et al. [15] revealed that the NAcc-DBS was less effective for weight restoration in patients with the bingeeating type of AN than in those with the restricting subtype (R-AN). There were noted, compared to presurgical levels, significant increases in BMI and improvement in psychiatric scale stores during the 6-month follow-up of 28 patients with $\mathrm{AN}$ and the results were maintained at the 2-year review. The most common short-term side effect observed was varying degrees of pain at the incision sites ( $\mathrm{n}=22$ ), which usually disappeared 3-4 days following the operation. No severe surgical adverse events were observed. According to the authors, the DBS method may be effective in the treatment of chronic, resistant form of AN, however, it is still an experimental method that requires further research. It therefore seems reasonable to develop specific patient inclusion and exclusion criteria that will help guide researchers through the ethical implications of treating this disease. Steps such as assessing individual needs, possible risks and benefits, considering mental performance, informed consent and future care after participation in the study [16].

\section{Affective disorders}

High percentage of recurrence was observed among the patients, together with lack of expected improvement, despite the pharmacological treatment. Such observations create an urgent need to search for new therapeutic methods. In the case of patients suffering from affective disorders resistant to pharmacological treatment deep brain stimulation (DBS) shows as a promising method [17].

Holtzheimer et al. analyzed the effectiveness of this therapy on 17 patients, including 7 with major depressive disorder and 10 with bipolar disorders. Electrodes were implanted bilaterally in the subcallosal 
cingulate white matter. To assess the effectiveness of research the HDRS, BDI-II and GAF scales were used. The longitudinal change in HDRS over time was the primary outcome measure. Compared with baseline state (the time before the implantation), there was an improvement in depressive symptoms - average HDRS score decreased by $43.6 \%$ within 24 weeks, $43.0 \%$ within a year and $70.1 \%$ in 2 years after surgery. It is worth mentioning that in patients with bipolar disorder and depression, the effectiveness of DBS therapy was similar. The study used cutoffs on the HDRS scale to group patients into patients who achieved remission (HDRS <9), patients with mild depression (HDRS 8-15) and patients with moderate-tosevere depression (HDRS $>15$ ). After 2 years of continuous stimulation remission was observed in $58 \%$ of patients and $92 \%$ had a positive response to the treatment (decrease in HDRS score). Additionally, one patient with MDD decided to end the study due to lack of efficacy after 88 weeks of active stimulation. During the stimulation side effects occurred in 13 patients, but none of them was related to active stimulation. There were 2 suicide attempts. In both cases suicidal ideation resolved by itself and treatment was continued - both patients responded positively to treatment after the end of the study. There were no manic or hypomanic episodes during the study, which is important for patients with bipolar disorder [18].

Bewernick et al. conducted a study that lasted over 2 years, in which 11 patients aged 32-65 years suffering from drug-resistant depression participated. In the patients, the stimulated area of the brain was the nucleus accumbens (NAcc, org. Nucleus accumbens). Main measures were clinical effects (HDRS, MADRS, HAM-A), QoL (SF-36), cognition and positive activities (the Hautzinger list) of the patient. Measurements were performed on a weekly basis during the first and second month after stimulation, up to half a year on a 2-weekly basis, from month 7 up to 2 years patients were tracked on a monthly basis, then up to 4 years on a 3-monthly basis. After the first month of stimulation, five patients (45.5\%) responded positively to treatment, and the remaining six patients (54.5\%) were considered as non-responders, based on the HDRS scale. During the study the ratio of responders to non-responders did not change, and the improvement obtained in five patients was maintained for the next 4 years. Adverse events experienced by participants were related to the surgical procedure, parameter change or were unrelated to the DBS treatment. Side effects caused by DBS were transient or could be stopped by change in stimulation parameters, hence patients did not experience permanent adverse effects [19].

The mechanism of action of DBS is strongly correlated with the location of the stimulation. Subsequently, the studies that described the effects of DBS on different regions of the brain were compared.

In Kennedy's study, the subcallosal cingulate gyrus (Brodmann's area 25) was stimulated. The observation of the subjects lasted up to three years, with the last visit up to the sixth year. The number of 20 patients participated in the study. In the observed-case analysis, the percentage of patients who responded was $62.5 \%$ after 1 year, $46.2 \%$ after 2 years, $75.0 \%$ after 3 years, and $64.3 \%$ at last followup visit. The primary effectiveness outcome measure was the percentage of patients who had responded by the time of the last follow-up visit. Secondary outcome measures were the percentage of patients in remission, the absolute change in HAM-D scores out to 3 years and at last followup visit, and changes in functioning from baseline on the SF-36. It is worth noting that in the third year of the study and during the last visit, $1 / 3$ of patients achieved remission. However, during the observation period, two patients committed suicide [20].

Among 25 patients with drug-resistant depression, reduction of depressive symptoms was observed in approximately 40 to $60 \%$ of patients after DBS therapy. During long-term follow-up, the majority of patients showed a stable clinical status in response to DBS and tolerated the treatment well. Unfortunately, there were four serious adverse events during the study, including one suicide attempt, that could not be attributed with certainty to treatment. One of the patients who responded well to the therapy had a battery in the pacemaker depleted, which led to a rapid increase in symptoms of depression and the appearance of suicidal thoughts. This event demonstrates that the sudden discontinuation of stimulation can result in a recurrence of depressive symptoms. The results of DBS therapy are satisfactory, which enables further support in research into this method of treatment for patients with drug-resistant depression [21].

\section{Schizophrenia}

Deep brain stimulation is a method of treatment that offers hope for treating many psychiatric and neurological conditions. There have been reports of the effectiveness of this method in drug-resistant schizophrenia. To date, there is one completed study in schizophrenia in which seven refractory patients received DBS in the pre-spinal cingulate cortex or nucleus accumbens. PET 18 F-FDG analysis showed local changes in glucose metabolism, which correlated with clinical improvement in psychotic symptoms. This suggests that DBS acts by modulating cerebral function in the basal-thalamocortical circuit. There are only preliminary findings that require further research [22]. 
Table 1. A summary of studies conducted on various groups of patients in individual disease entities, which indicate an improvement in the mental state after the application of deep brain stimulation.

\begin{tabular}{|c|c|c|c|c|c|c|}
\hline & Rating scale & $\begin{array}{l}\text { Observation } \\
\text { time }\end{array}$ & Effects after DBS & Research group & $\begin{array}{l}\text { Mode of } \\
\text { action }\end{array}$ & Source \\
\hline \multirow[t]{2}{*}{$\begin{array}{l}\text { Obsessive- } \\
\text { compulsive } \\
\text { disorder }\end{array}$} & $\begin{array}{l}\text { Yale-Brown } \\
\text { Scale } \\
\text { (Y-BOCS) }\end{array}$ & - & reduction by $38.68 \%$ & $\begin{array}{l}80 \text { patients } \\
\text { with treatment- } \\
\text { resistant } \\
\text { obsessive- } \\
\text { compulsive } \\
\text { disorder }\end{array}$ & - & $\begin{array}{l}\text { Deep brain stimulation for } \\
\text { obsessive-compulsive disorder: } \\
\text { A systematic review of } \\
\text { randomised controlled trials. } \\
\text { Vicheva P et al., } 2020 .\end{array}$ \\
\hline & $Y$-BOCS & 12 months & $\begin{array}{l}52 \% \text { of patients reduction by } \geq 35 \% \text {, } \\
17 \% \text { of patients reduction by } 25-34 \%\end{array}$ & $\begin{array}{l}70 \text { patients } \\
\text { with severe } \\
\text { and intractable } \\
\text { obsessive- } \\
\text { compulsive } \\
\text { disorder }\end{array}$ & $\begin{array}{l}\text { bilateral } \\
\text { ventral } \\
\text { anterior } \\
\text { limb of the } \\
\text { internal } \\
\text { capsule }\end{array}$ & $\begin{array}{l}\text { Deep Brain Stimulation } \\
\text { for Intractable Obsessive- } \\
\text { Compulsive Disorder: Progress } \\
\text { and Opportunities } \\
\text { Goodmad WK et al., } 2020 .\end{array}$ \\
\hline \multirow[t]{3}{*}{$\begin{array}{l}\text { Anorexia } \\
\text { nervosa }\end{array}$} & $Y$-BOCS & 9 months & $\begin{array}{l}\text { average baseline BMI: } 13.7 \mathrm{~kg} / \mathrm{m} 2 \text {; average } \\
\text { BMI pre-surgery: } 16.1 \mathrm{~kg} / \mathrm{m} 2 ; \text { average } \\
\text { BMI at } 9 \text { month follow-up: } 16.6 \mathrm{~kg} / \mathrm{m} 2 \text {. } \\
\text { Improvements in Y-BOCS at } 6 \text { month follow- } \\
\text { up; Improvements in quality of life }(n=3)\end{array}$ & $\begin{array}{l}6 \text { adult patients } \\
\text { with treatment- } \\
\text { refractory } A N\end{array}$ & $\begin{array}{l}\text { Subcallosal } \\
\text { cingulate }\end{array}$ & $\begin{array}{l}\text { Subcallosal cingulate } \\
\text { deep brain stimulation for } \\
\text { treatment-refractory anorexia } \\
\text { nervosa: a phase } 1 \text { pilot trial. } \\
\text { Lancet. Lipsman } N \text { et al., } 2013 .\end{array}$ \\
\hline & $\begin{array}{l}\text { Y-BOCS, } \\
\text { Hamilton } \\
\text { Depression } \\
\text { Scale } \\
(\text { HAMD) }\end{array}$ & 38 months & $\begin{array}{l}\text { 1) Average of } 65 \% \text { increase in body weight } \\
\text { at } 38 \text {-month follow-up (average baseline } \\
\text { BMI: } 11.9 \mathrm{~kg} . \mathrm{m} 2 \text {; average BMI at follow-up: } \\
\text { 19.6 kg/2); } \\
\text { 2) restoration of the menstrual cycle }(n=4) \\
\text { 3) regaining school functioning }(n=3) \\
\text { 4) remission of AN according to the DSM-IV } \\
(n=4)\end{array}$ & $\begin{array}{l}4 \text { patients with } A N \\
\text { (14-16 years old) }\end{array}$ & $\begin{array}{l}\text { Nucleus } \\
\text { accumbens }\end{array}$ & $\begin{array}{l}\text { Deep-brain stimulation for } \\
\text { anorexia nervosa. Wu H et al., } \\
2012 .\end{array}$ \\
\hline & $\begin{array}{l}\text { Y-BOCS, } \\
\text { HAMD, } \\
\text { Hamilton } \\
\text { anxiety } \\
\text { Scale } \\
\text { (HAMA) }\end{array}$ & 2 years & $\begin{array}{l}\text { 1) } 18 \% \text { of patients reported increases by } \\
>30 \% \text {, with their BMI closely reaching } \\
\text { the lower threshold of the normal range } \\
\text { (16-18.5 } \mathrm{kg} / \mathrm{m} 2) \\
\text { 2) the mean } Y \text {-BOCS score significantly } \\
\text { improved during the } 6 \text {-month review } \\
(13.29 \pm 6.65, t=-5.302, p<0.001) \text { and } \\
\text { was maintained at the } 2 \text {-year follow-up } \\
\text { (13.04 } \pm 9.61, t=-5.724, p<0.001) \\
\text { 3) HAMA and HAMD significantly } \\
\text { ameliorated during the } 6 \text { - and } 24 \text {-month } \\
\text { follow-ups }\end{array}$ & $\begin{array}{l}28 \text { women with } \\
\text { refractory } A N\end{array}$ & $\begin{array}{l}\text { Nucleus } \\
\text { accumbens }\end{array}$ & $\begin{array}{l}\text { Deep brain stimulation of } \\
\text { the nucleus accumbens for } \\
\text { treatment-refractory anorexia } \\
\text { nervosa: A long-term follow-up } \\
\text { study. Brain Stimulation. Liu } W \\
\text { et al., } 2020 .\end{array}$ \\
\hline \multirow[t]{3}{*}{$\begin{array}{l}\text { Affective } \\
\text { Disorders }\end{array}$} & $\begin{array}{l}\text { Hamilton } \\
\text { Depression } \\
\text { Rating Scale } \\
\text { (HDRS) }\end{array}$ & $2-4$ years & $\begin{array}{l}45.4 \% \text { of patients responded positively } \\
\text { to stimulations, the improvement was } \\
\text { maintained for the next } 4 \text { years }\end{array}$ & $\begin{array}{l}11 \text { patients } \\
\text { with treatment- } \\
\text { resistant } \\
\text { depression }\end{array}$ & $\begin{array}{l}\text { Nucleus } \\
\text { accumbens }\end{array}$ & $\begin{array}{l}\text { Long-term effects of nucleus } \\
\text { accumbens deep brain } \\
\text { stimulation in treatment- } \\
\text { resistant depression: evidence } \\
\text { for sustained efficacy. } \\
\text { Bewernick LH et al., } 2012 .\end{array}$ \\
\hline & $\begin{array}{l}\text { Hamilton } \\
\text { Depression } \\
\text { Rating Scale } \\
\text { (HDRS) }\end{array}$ & 3-6 years & $\begin{array}{l}\text { 1) The average response rates: } 62.5 \% 1 \\
\text { year after implantation, } 46.2 \% \text { after } 2 \\
\text { years, } 75.0 \% \text { after } 3 \text { years and } 64.3 \% \text { at the } \\
\text { last follow-up visit (range }=3-6 \text { years) } \\
\text { 2) At the beginning HDRS }=24.4 \text {, after } 3 \\
\text { years } H D R S<10 \text {, at the last follow-up } \\
H D R S=10 \text {. }\end{array}$ & $\begin{array}{l}20 \text { patients } \\
\text { with treatment- } \\
\text { resistant } \\
\text { depression }\end{array}$ & $\begin{array}{l}\text { subcallosal } \\
\text { cingulate } \\
\text { gyrus }\end{array}$ & $\begin{array}{l}\text { Deep brain stimulation for } \\
\text { treatment-resistant depression: } \\
\text { follow-up after } 3 \text { to } 6 \\
\text { years. Kennedy SH et al., } 2011 \text {. }\end{array}$ \\
\hline & $\begin{array}{l}\text { Hamilton } \\
\text { Depression } \\
\text { Rating Scale } \\
\text { (HDRS), } \\
\text { Beck } \\
\text { Depression } \\
\text { Inventory } \\
\text { - Second } \\
\text { Edition } \\
\text { (BDI-II) }\end{array}$ & 2 years & $\begin{array}{l}\text { 1) Average HDRS score decreased by } 43.6 \% \\
\text { within } 24 \text { weeks, } 43.0 \% \text { within a year and } \\
70.1 \% \text { in } 2 \text { years after surgery. After } 2 \text { years } \\
\text { of continuous stimulation remission was } \\
\text { observed in } 58 \% \text { of patients and } 92 \% \text { had a } \\
\text { positive response to the treatment. } \\
\text { 2) Average HDRS score, baseline } 23.9, \text { after } \\
1 \text { year of active stimulation } 13.6 \text { and } 7.3 \\
\text { after } 2 \text { years of active stimulation. } \\
\text { 3) BDI-II, baseline } 38.4 \text {, after } 1 \text { year of } \\
\text { active stimulation } 20.8 \text { and } 9.5 \text { after } 2 \\
\text { years of active stimulation. }\end{array}$ & $\begin{array}{l}17 \text { patients, } \\
\text { including } 10 \text { with } \\
\text { depression and } \\
7 \text { with bipolar } \\
\text { affective disorder }\end{array}$ & $\begin{array}{l}\text { subcallosal } \\
\text { cingulate } \\
\text { gyrus }\end{array}$ & $\begin{array}{l}\text { Subcallosal Cingulate Deep } \\
\text { Brain } \\
\text { Stimulation for Treatment- } \\
\text { Resistant } \\
\text { Unipolar and Bipolar } \\
\text { Depression } \\
\text { Holtzheimer et al., } 2012\end{array}$ \\
\hline
\end{tabular}




\section{Discussion}

Evidence for the efficacy and safety of DBS in the disease entities mentioned by us is promising and we should continue to search for optimal target brain structures for which stimulation will work best. The results in the table show the greatest effectiveness of DBS in Obsessive-Compulsive Disorders. Various areas of the brain were subjected to stimulation, such as: the ventral anterior branch of the inner capsule, the subspoid cingulate gyrus and nucleus accumbens. Research groups ranged from 4 to 80 patients. All the patients did not respond to pharmacological treatment and their condition was assessed as severe. We interpreted the results of the Y-BCOS and HAMD, HAMA and HDRS scores. This is especially interesting because the improvement in the results came after a different time. In some cases, DBS may exacerbate hypomania or cause transient impulsivity. The arguments suggest that the application of deep brain stimulation can inhibit the development of acute patients'

\section{Wstęp}

Współczesne rozumienie mechanizmów chorób i zaburzeń psychicznych akcentuje, że obserwowalne objawy behawioralne mają podłoże neurobiologiczne, np. polegające na hipofunkcji oraz hiperfunkcji pewnych okolic mózgu, zarówno korowych, jak i podkorowych. W związku z czym, można założyć, że modulowanie poziomu pobudzenia tych struktur powinno oddziaływać terapeutycznie. Na takim założeniu opiera się głęboka stymulacja mózgu (DBS, org. Deep Brain Stimulation), będąca metodą leczenia zaburzeń neurologicznych i psychiatrycznych, w której impulsy elektryczne są dostarczane do określonych obszarów mózgu za pośrednictwem wszczepionych elektrod i generatora impulsów [1].

DBS może bezpośrednio zmieniać aktywność mózgu w sposób kontrolowany, a efekt jest odwracalny. Mechanizm polega na miejscowym działaniu elektrody na aktywność neuronalną, która jest przekazywana do monosynchronicznych i wielosynaptycznych połączeń sieciowych. Stymulacja DBS wymaga zabiegu operacyjnego, któremu podlega wybrana okolica mózgu. Układ, który jest wykorzystywany w DBS składa się $\mathrm{z}$ generatora rytmicznej czynności elektrycznej, doprowadzenia sygnału do odpowiedniego jądra mózgu, która jest połączona $\mathrm{z}$ elektrodą mózgową specjalnym przewodem (łącznikiem). Potencjalne ryzyko związane z DBS obejmuje ryzyko związane z zabiegami chirurgicznymi, w tym małe $(<1 \%)$ ryzyko krwotoku śródczaszkowego lub zakażenia oraz związane z tym konsekwencje neurologiczne. Ponadto niektórzy pacjenci mogą wykazywać przejściowe objawy neurologiczne (np. Zaburzenia ruchu gałek ocznych), które zwykle ustępują condition and improve both psychiatric features and the duration of remission. Therefore, brain stimulation may be a promising therapeutic target in mental illness. Pacing protocols have not yet been clearly defined, and pacemaker implantation in psychiatry remains an experimental study. New research is needed that would confirm the effectiveness of this method, and at the same time would support the introduction of DBS intervention as an integral part of treatment in psychiatric departments.

\section{Conclusions}

1. The greatest effectiveness of deep brain stimulation was observed in Obsessive-Compulsive Disorders.

2. It is essential to look for new treatment options that focus on the impact on the underlying neurobiological mechanisms of the disease, but also on its safety and long-term effectiveness.

samoistnie lub po pewnym dostrojeniu stymulatora [2].

Głęboka stymulacja mózgu po raz pierwszy w psychiatrii została wykorzystana w 1948 roku przez Poola. Zastosował tę metodę u pacjentki z Chorobą Parkinsona, u której dodatkowo występowały objawy ciężkiej depresji. Wtedy uważano, że taka stymulacja może być pomocna w kontrolowaniu skutków ubocznych przyjmowanych leków, jednakże metoda pozostawała nie do końca rozumiana [3].

W 2002 roku FDA wydała zgodę na zastosowanie stymulacji jądra niskowzgórzowego (Subthalamic Nucleus - STN) i gałki bladej wewnętrznej (łac. globus pallidus internus - GPi) w leczeniu Choroby Parkinsona, a od 2003 w zaburzeniach osobowości [4]. Obecnie DBS jest stosowany, choć poza wskazaniami, w leczeniu dużej depresji. Jednakże neuropatofizjologia chorób psychicznych pozostaje słabo zdefiniowana, a mechanizm DBS wydaje się zależeć od miejsca stymulacji [5].

\section{Metoda}

Przedstawiamy badania przeprowadzone na grupie pacjentów, które wskazują na poprawę stanu psychicznego po zastosowaniu DBS. Jednostki chorobowe, które wzięliśmy pod uwagę w naszej pracy to: zaburzenia obsesyjno-kompulsyjne, zaburzenia odżywiania, depresja i Choroba Afektywna Dwubiegunowa.

Kryteria, jakie zastosowaliśmy do wyboru prac to:

- pacjenci lekooporni

- ocena poprawy pacjentów wg Skal; Y-BOCS, HAMD, HDRS

- stymulowanie określonych części mózgu; jądro półleżące, podspoidłowy zakręt obręczy, odnoga torebki wewnętrznej 
- czas głębokiej stymulacji mózgu powyżej 9 miesięcy

\section{MATERIAt}

\section{Zaburzenia obsesyjno-kompulsywne}

Zaburzenie obsesyjno-kompulsyjne (OCD) jest to schorzenie, którego dwiema charakterystycznymi składowymi są myśli natrętne, definiowane jako nagłe niepożądane myśli wdzierające się do świadomości pacjenta oraz czynności natrętne, definiowane jako zachowania, których podstawową funkcją jest redukcja napięcia wywołanego przez myśl natrętną [6]. Etiologia OCD jest wieloczynnikowa- mają w niej swój udział czynniki genetyczne, biologiczne i środowiskowe, jednakże to właśnie na podłoże biologiczne schorzenia ukierunkowana jest terapia DBS. Głęboka stymulacja mózgu w OCD ma na celu modyfikować nieprawidłowości w aktywności połączeń neurologicznych obejmujących korę oczodołowo-czołową, zakręt obręczy i jądro ogoniaste [6].

Vicheva i inni ocenili stan afektywny, globalne funkcjonowanie, funkcje poznawcze i tolerancję DBS w grupie 80 pacjentów z OCD opornym na farmakoterapię - Terapię uznano za skuteczną, gdyż spowodowała zmniejszenie wyników skali Obsesyjno-Kompulsywnej Yale-Browna (Y-BOCS) średnio o 38,68\%. Większość zdarzeń niepożądanych była łagodna i przemijająca. Wystąpiło pięć ciężkich komplikacji związanych z operacją: krwotok śródmózgowy u trzech pacjentów i zakażenie okołooperacyjne związane z implantowanymi elementami u dwóch. Skutki zagrażające związane z nastrojem to jedno samobójstwo dokonane, trzy próby samobójcze, a u dwóch pacjentów myśli samobójcze i depresja u czterech. Stan afektywny pacjentów poprawił się po stymulacji [7].

Goodman i inni opisują odpowiedź 70 pacjentów leczonych głęboką stymulacją mózgu dwustronnie w obszarze brzusznej przedniej odnogi torebki wewnętrznej (vALIC). Celowość takiego umiejscowienia elektrod opiera się na założeniu, że ablacja włókien przebiegających przez przednią odnogę torebki wewnętrznej doprowadzi do normalizacji aktywności nadmiernie zsynchronizowanych sieci w OCD w całym obwodzie korowo-prążkowato-wzgórzowo-korowym. Ponadto, istnieje alternatywna, lecz uzupełniająca, hipoteza głosząca, że DBS w prążkowiu brzusznym w przypadku OCD wpływa na równowagę między dodatnimi i ujemnymi systemami walencyjnymi w mózgu, w taki sposób, że odchylenie obwodu zmienia się w kierunku układu nagrody zamiast unikania kary, co jest odwróceniem zaburzenia obecnego w OCD. Kompulsje mają na celu zapobieganie negatywnym skutkom i nie są satysfakcjonujące, co odróżnia je od uzależnień behawioralnych. Niestety, niedostateczne monitorowanie terapii może doprowadzić do nadmiernego poszukiwania nagrody, co przejawia się jako przejściowe stany hipomanii. W powyższym badaniu, po 12 miesiącach obserwacji, stwierdzono spadek skali Obsesyjno-Kompulsywnej Yale-Browna (Y-BOCS)o $\geq 35 \%$ w 52\% przypadków oraz o 25-34\% w 17 \% przypadków. Jednakże, pomimo rosnącej liczby dowodów na skuteczność DBS w terapii OCD, nie można nie wspomnieć o wątpliwym profilu bezpieczeństwa tej metody. Autorzy odnotowali 11 poważnych zdarzeń niepożądanych, w tym $2 \mathrm{w}$ postaci pooperacyjnych infekcji. Nie odnotowano krwotoków śródmózgowych ani drgawek. Wystąpiły trzy przypadki prób samobójczych bez następstw, z czego jedna została sklasyfikowana jako związana ze zmianami stymulacji. U 39\% pacjentów wystąpiła przejściowa hipomania [8].

Beszłej J. I inni przedstawiają dwa przypadki, w których zastosowano DBS w zaburzeniach obsesyjno - kompulsywnych. Opisani pacjenci zostali poddani zabiegowi wszczepienia elektrod, w celu zmniejszenia patologicznie nadaktywnych pętli neuronowych. Pacjentów kontrolowano co dwa tygodnie przez okres 6 miesięcy, po czym podjęto próbę wyłączenia stymulatora. Stan chorej uległ pogorszeniu, zaś po ponownym włączeniu uzyskano znaczną poprawę stanu psychicznego. Zaobserwowano spadek obsesji i kompulsji o 35\% punktów w skali Y-BOCS do początkowego wyniku. Drugi pacjent początkowo po wszczepieniu stymulatora przez neurochirurgów uzyskał taki sam wynik, jak przed zabiegiem. Dopiero podczas drugiego badania odnotowano spadek o $36 \%$ w skali Y-BOCS. W ciągu trzech dni od procedury wyłączenia stymulatora nastrój pacjenta uległ znacznemu pogorszeniu. Po ponownym włączeniu nastąpiła poprawa samopoczucia [9].

$\mathrm{Na}$ podstawie licznych doniesień można wysnuć wniosek, że DBS jest skuteczną metodą w leczeniu opornych na farmakoterapię przypadków zaburzeń obsesyjno-kompulsywnych. Niestety, nadal nie ma ustalonych klinicznych predyktorów, które informowałyby, którzy pacjenci zareagują na DBS. Ponadto, inwazyjność metody zmusza do rozważenia ryzyka w stosunku do potencjalnych korzyści [8].

\section{Jadłowstręt psychiczny}

Ponieważ istnieje niewiele metod leczenia AN opartego na dowodach naukowych, kluczowe znaczenie ma zbadanie nowych opcji leczenia. Jedną z nich jest głęboka stymulacja mózgu ukierunkowana na neurobiologiczne mechanizmy AN powiązane ze zmienną aktywnością receptorów serotoninowych i dopaminowych, co wpływa na rozregulowanie układów zaangażowanych w nastrój, lęk, apetyt i kontrolę impulsów 
[10]. Rolę w etiopatogenezie odgrywają m.in. przednia część wyspy, okolice prążkowia, przednia część zakrętu obręczy odpowiedzialne za odczuwanie smaku [11], kora przedczołowa, odpowiedzialna za zdolność do właściwej lub niewłaściwej kontroli przyjmowania pokarmów [12] oraz struktury mózgu związane z układem nagrody takie jak jądro półleżące czy wspomniana już przednia część zakrętu obręczy.

Pierwsze badania (na podstawie serii przypadków) dotyczące zastosowania DBS w leczeniu AN przeprowadzili badacze Sun i inni [13]. Wstępne wyniki wykazały wzrost masy ciała o 65\% w 38-miesięcznej obserwacji u czterech nastoletnich pacjentek z AN leczonych DBS jądra półleżącego. Wszystkie cztery pacjentki zostały zawieszone w szkole ze względu na ciężki stan zdrowia fizycznego i psychicznego przed implantacją, a ostatecznie trzy z nich były w stanie kontynuować naukę w szkole. Lipsman i inni [14] w 9-miesięcznym okresie obserwacji stwierdzili poprawę BMI u 3 na 6 dorosłych pacjentów z AN opornym na leczenie. Zanotowano jednak kilka działań niepożądanych terapii DBS podspoidłowego zakrętu obręczy (ACC), z czego jednymi z najpoważniejszych był napad padaczkowy u jednego z pacjentów podczas programowania urządzenia oraz hipofosfatemia i majaczenia wywołane zespołem ponownego odżywienia $\mathrm{u}$ innego z pacjentów. Zespół ten może wystąpić na skutek szybkiego przyrostu masy ciała po skutecznym leczeniu DBS, dlatego takim pacjentom należy zalecić stopniowe zwiększanie spożycia pokarmu pod nadzorem konsultanta dietetycznego. Stan somatyczny i możliwość wystąpienia zespołu ponownego odżywienia powinny być ściśle monitorowane przez lekarza.

Wei Liu i inni [15] wykazali, że NAcc-DBS był mniej skuteczny $\mathrm{w}$ przywracaniu masy ciała u pacjentów z podtypem AN z napadowym objadaniem się niż u pacjentów z podtypem restrykcyjnym (RAN). Podczas 6 miesięcznej obserwacji 28 pacjentów z AN odnotowano znaczący wzrost BMI i poprawę wyników w skali psychiatrycznej w porównaniu z poziomami przedoperacyjnymi, a wyniki utzymywały się przez 2 lata trwania badania. Najczęściej obserwowanym krótkotrwałym efektem ubocznym był ból w miejscu nacięcia ( $\mathrm{n}=22$ ) o różnym nasileniu, który zwykle ustępował 3-4 dni po operacji. Nie zaobserwowano żadnych poważnych chirurgicznych działań niepożądanych. Według autorów metoda DBS może być skuteczna w leczeniu przewlekłej, opornej postaci AN, jednakże pozostaje wciąż metodą eksperymentalną, wymagającą dalszych badań. Zasadne więc zdaje się być opracowanie szczegółowych kryteriów włączenia i wyłączenia pacjentów, które pomogą poprowadzić badaczy przez etyczne implikacje związane z leczeniem tej choroby. Etapy takie, jak ocena indywidualnych potrzeb oraz możliwych zagrożeń i korzyści, rozważenie kwestii sprawności umysłowej i świadomej zgody oraz rozważenie przyszłej opieki po udziale w badaniu [16].

\section{Zaburzenia afektywne}

Wysoki odsetek nawrotów i duża liczba osób, którzy pomimo zastosowanego leczenia farmakologicznego nie uzyskały oczekiwanej poprawy klinicznej, uzasadniają pilną potrzebę poszukiwania nowych metod terapeutycznych. W przypadku osób cierpiących na zaburzenia afektu, u których objawy nie poddają się leczeniu, metoda DBS może okazać się obiecująca [17].

Holtzheimer'a i inni przeanalizowali skuteczność DBS na 17 pacjentach w wieku 18-70 lat, w tym 7 z nich z zaburzeniami depresyjnymi oraz $10 \mathrm{z}$ chorobą afektywną dwubiegunową. Elektrody zostały zaimplantowane obustronnie w podspoidłowej części zakrętu obręczy. Do oceny skuteczności badania posłużono się skalami HDRS, BDI-II oraz GAF. Podstawową miarą wyników badania była zmiana HDRS w czasie. W porównaniu ze stanem wyjściowym (okresem sprzed wszczepienia implantów) uzyskano poprawę w zakresie objawów depresyjnych - średni wynik HDRS spadł o 43,6\% w ciągu 24 tygodni, $43,0 \%$ w ciągu roku oraz $70,1 \%$ w ciągu 2 lat po zabiegu. Warto wspomnieć, że u pacjentów z ChAD i depresją skuteczność terapii DBS była podobna. W badaniu zastosowano odcięcia w skali HDRS, by pogrupować pacjentów na tych, co uzyskali remisję (HDRS <8), z łagodną depresją (HDRS 8-15) oraz z umiarkowaną lub ciężką depresą (HDRS >15). Po 2 latach ciągłej stymulacji $58 \%$ badanych uzyskało remisję, a pozytywną reakcję na leczenie (spadek punktów w skali HDRS) aż 92\%. Jeden pacjent z depresją zdecydował się zakończyć badanie z powodu braku skuteczności po 88 tygodniach aktywnej stymulacji. Podczas stymulacji wystąpiły działania niepożądane u 15 pacjentów, jednak żadne z nich nie były powiązane $\mathrm{z}$ aktywną stymulacją. Były dwie próby samobójcze. W tym przypadku myśli samobójcze ustapiły samoistnie, a leczenie było kontynuowane u obu z badanych zaobserwowano pozytywną reakcję na leczenie po zakończeniu badania. Nie wystąpiły epizody manii ani hipomanii, co jest istotne w przypadku leczenia osób z chorobą afektywną dwubiegunową [18].

W 2-letnim badaniu Bewernick'a i wsp. wzięło udział 11 pacjentów w wieku $32-65$ lat cierpiących na depresję lekooporną. U badanych stymulowanym obszarem mózgu było jądro półleżące (NAcc, org. nucleus accumbens). Głównymi analizowanymi wskaźnikami były: efekt kliniczny mierzony za pomocą HDRS, MADRS, skali leku Hamiltona, QoL, funkcji poznawczych oraz aktywności na początku badania, w 3, 6, 9, 12, 15, 18, 21 oraz 24 miesiącu z ostatnim badaniem do 4 roku (u niektórych badanych). Już po pierwszym miesiącu stymulacji u pięciu pacjentów 
(45,5\%) osiągnięto pozytywną odpowiedź na leczenie, a pozostałych sześciu pacjentów $(54,5 \%)$, bazując na skali HDRS, uznano za niereagujących na stymulację. W trakcie badania stosunek pacjentów reagujących do niereagujących na stymulację nie uległ zmianie, a poprawa uzyskana u pięciu badanych utrzymywała się przez okres kolejnych 4 lat. Występujące u badanych zdarzenia niepożądane związane były z zabiegiem chirurgicznym, zmianą parametrów lub niezwiązane z terapią DBS. Skutki uboczne, które były wynikiem stymulacji, były przemijające lub można je było zatrzymać poprzez zmianę natężenia prądu, dzięki czemu pacjencji nie odczuli trwałych efektów niepożądanych [19].

Mechanizm działania DBS jest istotnie skorelowany z lokalizacją stymulacji. W dalszej kolejności porównano badania, w których opisano wpływ działania DBS na różne okolice mózgu. W przypadku badania Kennedy'ego stymulowano podspoidłowy zakręt obręczy (25 pole Brodmanna). Obserwacja badanych trwała do trzech lat z ostatnią wizytą do 6 roku. W analizie obserwowanych przypadków odsetek dobrze reagujących na stymulację wyniósł $62,5 \%$ po 1 roku, 46,2\% po 2 latach, $75,0 \%$ po 3 latach oraz $64,3 \%$ podczas ostatniej wizyty. Podstawowym kryterium oceny skuteczności leczenia był odsetek pacjentów, u których pozytywny efekt terapeutyczny obserwowany był aż do ostatniej wizyty kontrolnej. Drugim z kolei kryterium były: odsetek pacjentów z remisją, zmiana w wynikach HAMD w ciągu 3 lat badania i podczas ostatniej wizyty kontrolnej oraz zmiany w funkcjonowaniu w stosunku do wartości wyjściowej w Kwestionariuszu oceny jakości życia SF-36. Warto zwrócić uwagę na fakt, iż w 3 roku badania oraz podczas ostatniej wizyty $1 / 3$ pacjentów uzyskała remisję. W trakcie obserwacji 6 pacjentów było hospitalizowanych z powodów psychiatrycznych - myśli samobójczych oraz pogarszającej się depresji [20].

U 25 pacjentów z depresją lekooporną po zastosowaniu terapii DBS zaobserwowano redukcję objawów depresyjnych u około 40 do $60 \%$ pacjentów. Podczas długotrwałej obserwacji większość pacjentów wykazywała stabilny stan kliniczny w odpowiedzi na DBS i dobrze tolerowała leczenie. Niestety podczas badania wystąpiły cztery poważne niepożądane zdarzenia, w tym jedna próba samobójcza, których nie można było z całą pewnością przypisać terapii. U jednego z dobrze odpowiadających na terapię pacjentów doszło do wyczerpania baterii w stymulatorze, co doprowadziło do gwałtownego wzrostu objawów depresji i pojawieniu się myśli samobójczych. To zdarzenie ukazuje, że nagłe przerwanie stymulacji może skutkować nawrotem objawów depresyjnych. Wyniki terapii DBS są zadowalające, co umożliwia dalsze wsparcie w badaniach nad tą metodą leczenia dla pacjentów z lekooporną depresją [21].

\section{Schizofrenia}

Głęboka stymulacja mózgu jest metodąleczenia, która daje nadzieje na leczenie wielu schorzeń psychiatrycznych i neurologicznych. Pojawiły się doniesienia o skuteczności tejże metody w schizofrenii lekoopornej. Jak dotąd jedno zakończone badanie dotyczące schizofrenii, w którym siedmiu pacjentów opornych na leczenie otrzymało DBS w przedrdzeniowej korze zakrętu obręczy lub jądrze półleżącym. Analiza PET 18 F-FDG wykazała miejscowe zmiany metabolizmu glukozy, co korelowało z poprawą kliniczną w zakresie objawów psychotycznych. Sugeruje to, że DBS działa poprzez modulowanie czynności mózgowej w obwodzie korowo-podstawno-wzgórzowokorowym. Istnieją jedynie wstępne ustalenia, które wymagają dalszych badań [22].

\section{Dyskusja}

Dowody na skuteczność i bezpieczeństwo DBS w wymienionych przez nas jednostkach chorobowych są obiecujące i należy kontynuować poszukiwanie optymalnych docelowych struktur mózgu, na które stymulacja zadziała najlepiej. Wyniki zamieszczone w tabeli wskazują na największą skuteczność DBS w Zaburzeniach obsesyjno-kompulsyjnych. Stymulacji zostały poddane różne obszary mózgu takie jak: brzuszna przednia odnoga torebki wewnętrznej, podspoidłowy zakręt obręczy oraz jądro półleżące. Grupy badawcze wahały się w granicach 4-80 pacjentów. Wszyscy pacjenci nie reagowali na leczenie farmakologiczne, a ich stan oceniono na ciężki. Zinterpretowaliśmy wyniki skal: Y-BCOS oraz HAMD, HAMA, HDRS. Jest to szczególnie interesujące, ponieważ poprawa wyników nastąpiła po innym czasie. W niektórych przypadkach DBS może nasilać hipomanię lub powodować przemijającą impulsywność. Argumenty przemawiają za tym, że zastosowanie głębokiej stymulacji mózgu może hamować rozwinięcie się ostrego stanu pacjentów i poprawiać zarówno cechy psychiatryczne, jak i wpływać na czas remisji. Dlatego stymulacja mózgu może być obiecującym celem terapeutycznym w chorobach psychicznych. Protokoły stymulacji nie zostały jeszcze jasno określone, a wszczepienie rozrusznika $\mathrm{w}$ psychiatrii pozostaje dalej badaniem eksperymentalnym. Potrzeba nowych badań, które potwierdziłyby skuteczność tej metody, a jednocześnie byłyby wsparciem dla wprowadzenia interwencji DBS jako integralnej części leczenia na oddziałach psychiatrycznych. 
Tabela 1. Zestawienie badań przeprowadzonych na różnych grupach pacjentów w poszczególnych jednostkach chorobowych, które wskazują na poprawę stanu psychicznego po zastosowaniu głębokiej stymulacji mózgu.

\begin{tabular}{|c|c|c|c|c|c|c|}
\hline & Skala oceny & $\begin{array}{c}\text { Czas } \\
\text { obserwacji }\end{array}$ & Efekty po DBS & Grupa badawcza & $\begin{array}{c}\text { Sposób } \\
\text { działania }\end{array}$ & Źródło \\
\hline \multirow[t]{2}{*}{$\begin{array}{l}\text { Zaburzenia } \\
\text { obsesyjno - } \\
\text { kompulsyjne }\end{array}$} & $\begin{array}{l}\text { Yale-Brown } \\
\text { Scale } \\
(\text { Y-BOCS })\end{array}$ & - & spadek Y-BOCS о 38,68\%; & $\begin{array}{l}80 \text { pacjentów } z \\
\text { OCD opornym na } \\
\text { leczenie }\end{array}$ & - & $\begin{array}{l}\text { Deep brain stimulation } \\
\text { for obsessive-compulsive } \\
\text { disorder: A systematic review } \\
\text { of randomised controlled } \\
\text { trials. } \\
\text { Vicheva } P \text { et al., } 2020 .\end{array}$ \\
\hline & Y-BOCS & $\begin{array}{l}12 \\
\text { miesięcy }\end{array}$ & $\begin{array}{l}52 \% \text { badanych spadek o } \geq 35 \% \\
17 \% \text { badanych spadek o } 25-34 \%\end{array}$ & $\begin{array}{l}70 \text { pacjentów } \\
\text { z ciężkim i } \\
\text { nieuleczalnym } \\
\text { OCD }\end{array}$ & $\begin{array}{l}\text { Brzuszna } \\
\text { przednia } \\
\text { odnoga torebki } \\
\text { wewnętrznej }\end{array}$ & $\begin{array}{l}\text { Deep Brain Stimulation } \\
\text { for Intractable Obsessive- } \\
\text { Compulsive Disorder: } \\
\text { Progress and Opportunities } \\
\text { Goodmad WK et al., } 2020 .\end{array}$ \\
\hline \multirow[t]{3}{*}{$\begin{array}{l}\text { Zaburzenia } \\
\text { odżywiania }\end{array}$} & $Y-B O C S$ & 9 miesięcy & $\begin{array}{l}\text { średnie wyjściowe BMI: } 13,7 \mathrm{~kg} / \mathrm{m} 2 ; \\
\text { średnie BMI przed zabiegiem: } 16,1 \mathrm{~kg} / \mathrm{m} 2 ; \\
\text { średnie BMI po } 9 \text { miesiacach obserwacji: } \\
16,6 \mathrm{~kg} / \mathrm{m} 2) \\
\text { Po } 6 \text { miesiqcach Y-BOCS o Poprawa jakości } \\
\text { życia }(n=3)\end{array}$ & $\begin{array}{l}6 \text { dorosłych } \\
\text { pacjentów z } \\
\text { przewlekłym, } \\
\text { ostrym i opornym } \\
\text { na leczenie } \\
\text { jadłowstrętem } \\
\text { psychicznym }\end{array}$ & $\begin{array}{l}\text { Podspoidłowy } \\
\text { zakręt obręczy }\end{array}$ & $\begin{array}{l}\text { Subcallosal cingulate } \\
\text { deep brain stimulation } \\
\text { for treatment-refractory } \\
\text { anorexia nervosa: a phase } 1 \\
\text { pilot trial. Lancet. Lipsman } N \\
\text { et al., } 2013 .\end{array}$ \\
\hline & $\begin{array}{l}\text { Y-BOCS, } \\
\text { Hamilton } \\
\text { Depression } \\
\text { Scale } \\
\text { (HAMD) }\end{array}$ & $\begin{array}{l}38 \\
\text { miesięcy }\end{array}$ & $\begin{array}{l}\text { 1) Średnio 65\% wzrost masy ciała po } 38 \\
\text { miesiqcach obserwacji (średnie wyjściowe } \\
\text { BMI: } 11,9 \mathrm{~kg} / \mathrm{m} 2 ; \text { średnie BMI w okresie } \\
\text { obserwacji: } 19,6 \mathrm{~kg} / \mathrm{m} 2 \\
\text { 2) przywrócenie cyklu miesiączkowego (n } \\
=4) ; \\
\text { 3) odzyskanie funkcjonowania i powrót do } \\
\text { szkoły ( } \mathrm{n}=3 \text { ); } \\
\text { 4) remisja AN według DSM-IV }(n=4)\end{array}$ & $\begin{array}{l}4 \text { pacjentów z AN } \\
\text { (14-16lat) }\end{array}$ & Jądro półleżące & $\begin{array}{l}\text { Deep-brain stimulation for } \\
\text { anorexia nervosa. Wu H et } \\
\text { al., } 2012 .\end{array}$ \\
\hline & $\begin{array}{l}\text { Y-BOCS, } \\
\text { HAMD, } \\
\text { Hamilton } \\
\text { anxiety } \\
\text { Scale } \\
\text { (HAMA) }\end{array}$ & 2 lata & $\begin{array}{l}\text { 1) } 18 \% \text { pacjentów zgłosiło wzrost mc o> } \\
30 \% \text {, a ich BMI blisko dolnego progu normy } \\
\text { (16-18,5 kg / m2). } \\
\text { 2) Y-BOCS poprawił się istotnie podczas } \\
6 \text {-miesięcznego przeglądu }(13,29 \pm 6,65, \\
t=-5,302, p<0,001) \text { i utrzymywał się na } \\
\text { poziomie } 2 \text { lata obserwacji }(13,04 \pm 9,61, t \\
=-5,724, p<0,001) \text {. } \\
\text { 3) HAMA i HAMD uległy znacznej poprawie } \\
\text { w okresie obserwacji 6- i } 24-\text { miesięcznej. }\end{array}$ & $\begin{array}{l}28 \text { kobiet } \\
\text { z opornym } \\
\text { jadłowstrętem } \\
\text { psychicznym }\end{array}$ & Jądro półleżq̨ce & $\begin{array}{l}\text { Deep brain stimulation } \\
\text { of the nucleus accumbens } \\
\text { for treatment-refractory } \\
\text { anorexia nervosa: } \text { A long- } \\
\text { term follow-up study. Brain } \\
\text { Stimulation. Liu W et al., } \\
2020 .\end{array}$ \\
\hline \multirow[t]{3}{*}{$\begin{array}{l}\text { Zaburzenia } \\
\text { afektywne }\end{array}$} & $\begin{array}{l}\text { Hamilton } \\
\text { Depression } \\
\text { Rating Scale } \\
\text { (HDRS) }\end{array}$ & 2-4 lata & $\begin{array}{l}45,4 \% \text { badanych reagowało pozytywnie } \\
\text { na stymulacje, poprawa utrzymywała się } \\
\text { przez okres kolejnych } 4 \text { lat }\end{array}$ & $\begin{array}{l}11 \text { pacjentów } \\
\text { z depresja } \\
\text { lekoopornq }\end{array}$ & Jądro półleżq̨ce & $\begin{array}{l}\text { Long-term effects of nucleus } \\
\text { accumbens deep brain } \\
\text { stimulation in treatment- } \\
\text { resistant depression: evidence } \\
\text { for sustained efficacy. } \\
\text { Bewernick LH et al., } 2012 .\end{array}$ \\
\hline & $\begin{array}{l}\text { Hamilton } \\
\text { Depression } \\
\text { Rating Scale } \\
\text { (HDRS) }\end{array}$ & 3-6 lat & $\begin{array}{l}\text { 1) Odsetek dobrze reagujących na } \\
\text { stymulację wyniósł } 62,5 \% \text { po } 1 \text { roku, } 46,2 \% \\
\text { po } 2 \text { latach, } 75,0 \% \text { po } 3 \text { latach oraz } 64,3 \% \\
\text { podczas ostatniej wizyty. } \\
\text { 2) HDRS początkowo } 24,4 \text {, w } 3 \text { roku } \\
\text { badania HDRS < } 10, \text { podczas ostatniej } \\
\text { wizyty HDRS wynosiło } 10 .\end{array}$ & $\begin{array}{l}20 \text { pacjentów } \\
\text { z depresja } \\
\text { lekoopornq }\end{array}$ & $\begin{array}{l}\text { Podspoidłowy } \\
\text { zakręt obręczy }\end{array}$ & $\begin{array}{l}\text { Deep brain stimulation } \\
\text { for treatment-resistant } \\
\text { depression: follow-up after } 3 \\
\text { to } 6 \text { years. Kennedy SH et al., } \\
2011 .\end{array}$ \\
\hline & $\begin{array}{l}\text { Hamilton } \\
\text { Depression } \\
\text { Rating Scale } \\
\text { (HDRS), } \\
\text { Beck } \\
\text { Depression } \\
\text { Inventory } \\
\text { - Second } \\
\text { Edition } \\
\text { (BDI-II) }\end{array}$ & 2 lata & $\begin{array}{l}\text { 1) Średni wynik HDRS spadł o } 43,6 \% \text { w } \\
\text { ciagu } 24 \text { tygodni, } 43.0 \% \text { w ciagu roku oraz } \\
70,1 \% \text { w ciagu } 2 \text { lat po zabiegu. Po } 2 \text { latach } \\
\text { ciagłej stymulacji } 58 \% \text { badanych uzyskało } \\
\text { remisję, a pozytywnq reakcję na leczenie } \\
92 \% \text {. } \\
\text { 2) HDRS, wyjściowo } 23,9 \text {, po roku } 13,6 \text { ( u } 5 \\
\text { pacjentów z BP), po dwóch latach 7,3 (u } 3 \\
\text { pacjentów z BP); } \\
\text { 3) BDI-II, wyjściowo } 38,4 \text {, po roku 20,8 (u } 5 \\
\text { pacjentów z BP), po dwóch latach 9,5 (u } 3 \\
\text { pacjentów z BP }\end{array}$ & $\begin{array}{l}17 \text { pacjentów, } w \\
\text { tym } 10 \text { z depresja, } \\
7 \text { z } C h A D\end{array}$ & $\begin{array}{l}\text { Podspoidłowy } \\
\text { zakręt obręczy }\end{array}$ & $\begin{array}{l}\text { Subcallosal Cingulate Deep } \\
\text { Brain } \\
\text { Stimulation for Treatment- } \\
\text { Resistant } \\
\text { Unipolar and Bipolar } \\
\text { Depression } \\
\text { Holtzheimer et al., } 2012\end{array}$ \\
\hline
\end{tabular}




\section{WnioskI}

1. Największą skuteczność głębokiej stymulacji mózgu zaobserwowano w Zaburzeniach Obsesyjno-Kompulsyjnych.

2. Niezbędne jest szukanie nowych opcji leczenia, które koncentrują się na wpływie na leżące u podstaw mechanizmy neurobiologiczne choroby, ale również nad bezpieczeństwem tej metody i jej długoterminową skutecznością.

\section{Conflict of interest}

The authors have declared no conflict of interest.

\section{References:}

1. Graat I., Figee M. \& Denys D. The application of deep brain stimulation in the treatment of psychiatric disorders, International Review of Psychiatry, 2017;29:2, 178-190, DOI: 10.1080/09540261.2017.1282439

2. Zrinzo L, Foltynie T, Limousin P, Hariz MI: Reducing hemorrhagic complications in functional neurosurgery: a large case series and systematic literature review. J Neurosurg. 2012; 116: 84-94. 10.3171/2011.8.JNS101407.

3. Pool JL. Psychosurgery in older people. J Am Geriatr Soc 1954;2:456-66. U.S. Department of Health and Human Services.

4. FDA approves implanted brain stimulator to control tremors. Retrieved October 18, 2006

5. Drobisz D., Damborská A. Deep brain stimulation targets for treating depression. Behav Brain Res, 2019; 359, 266-273, doi:10.1016/j.bbr.2018.11.004

6. Grat I., Figee M., Denys D. The application of deep brain stimulation in the treatment of psychiatric disorders 2017; 178190.

7. Vicheva P, Butler M, Shotbolt P. Deep brain stimulation for obsessive-compulsive disorder: A systematic review of randomised controlled trials. Neuroscience \& Biobehavioral Reviews 2020; 109; 129-138.

8. Goodman WK, Storch EA, Cohn JF, Sheth SA. Deep Brain Stimulation for Intractable Obsessive-Compulsive Disorder: Progress and Opportunities. American Journal of Psychiatry 2020; 177(3): 200-203.

9. Beszłej JA, Siwicki D, et al. Głęboka stymulacja mózgu w zaburzeniu obsesyjno- kompulsyjnym - dwa przypadki kliniczne. Psychiatria Polska 2019; 53(4): 807-824.

10. Oudijn, M.S., Storosum, J.G., Nelis, E. et al. Is deep brain stimulation a treatment option for anorexia nervosa?. BMC Psychiatry 2013; 13, 277.

11. Wagner A, Aizenstein H, Mazurkewicz L, Fudge J, Frank GK, Putnam K, et. al. Altered insula response to taste stimuli in individuals recovered from restricting-type anorexia nervosa.
Neuropsychopharmacology. 2008; 33: 513-523.

12. Frank GK., Kaye WH. Current status of functional imaging in eating disorders. Int J Eat Disord 2012; 45: 723-736.

13. Wu H., Van Dyck-Lippens PJ., Santegoeds R., Van KK., Gabriels L., Lin G., et. al. Deep-brain stimulation for anorexia nervosa. World Neurosurg. 2012; 80: S29.e1-S29.

14. Lipsman N, Woodside DB, Giacobbe P, Hamani C, Carter JC, Norwood SJ, et. al. Subcallosal cingulate deep brain stimulation for treatment-refractory anorexia nervosa: a phase 1 pilot trial. Lancet. 2013; 381: 1361-1370.

15. Liu W., Zhan S., Li D., et al. Deep brain stimulation of the nucleus accumbens for treatment- refractory anorexia nervosa: A longterm follow-up study. Brain Stimulation 2020; 13: 643-649

16. Silava L., Naciff T., Oliveira M. Deep Brain Stimulation as a Treatment Approach for Anorexia Nervosa: a Systematic Literature Review. Arquivos Brasileiros de Neurocirurgia: Brazilian Neurosurgery 2019; 38(03): 175-182

17. Bilikiewicz A. Psychiatria. Podręcznik dla studentów medycyny. Warszawa, Polska: PZWL Wydawnictwo Lekarskie; 2011.

18. Holtzheimer PE., Kelley ME., Gross RE., et al. Subcallosal cingulate deep brain stimulation for treatment-resistant unipolar and bipolar depression. Archives Of General Psychiatry 2012;69(2): 150-158.

19. Bewernick BH., Kayser S., Sturm V., Schlaepfer TE. Longterm effects of nucleus accumbens deep brain stimulation in treatment-resistant depression: evidence for sustained efficacy. Neuropsychopharmacology. 2012;37(9):1975-1985.

20. Kennedy SH., Giacobbe P., Rizvi SJ., et al. Deep brain stimulation for treatment-resistant depression: follow-up after 3 to 6 years. American Journal of Psychiatry 2011;168(5):502-510.

21. Van der Wal JM., Bergfeld IO., Lok A., et al. Long-term deep brain stimulation of the ventral anterior limb of the internal capsule for treatment-resistant depression. Journal of Neurology, Neurosurgery and Psychiatry 2020; 91(2):189-195.

22. Beszłej JA, Wieczorek T, Kobyłko A, et al. Deep brain stimulation: new possibilities for the treatment of mental disorders. Głęboka stymulacja mózgu (Deep Brain Stimulation) - nowe możliwości leczenia zaburzeń psychicznych. Psychiatr Pol. 2019;53(4):789806. doi:10.12740/ PP/OnlineFirst/103090

\section{Corresponding author}

Małgorzata Romaniuk

Psychiatry Student Research Group I Department of Psychiatry, Psychotherapy and Early Intervention,

Medical University of Lublin

e-mail: goszarom@gmail.com

Otrzymano:24.08.2020

Zrecenzowano:25.08.2020

Przyjęto do druku: 27.08.2020 